\title{
Evaluation of effect of different pesticides on pigeon pea using statistical tools in field experiment.
}

\author{
Mrs. Manisha Jail ${ }^{1}$ Dr. Rasmi Urkude ${ }^{1}$ Dr. Lata Deshmukh ${ }^{2}$ \\ ${ }^{1}$ (Department of Chemistry, Hislop College, Nagpur, Maharashtra, India) \\ ${ }^{I}$ Department of Chemistry, Shivaji Science College, Nagpur, Maharashtra, India) \\ ${ }^{2}$ (Department of Chemistry, Hislop College, Nagpur, Maharashtra, India)
}

\begin{abstract}
Field study was conducted to evaluate the comparative efficacy of various concentrations of cypermethrin 25EC and chlorpyrifos 20EC against gram pod borer or bollworm Helicoverpa armigera on pigeonpea in the experimental research area of Nagpur region. Randomized block design was subjected in designing the field experiment to study pesticidal effect on $\mathrm{H}$. armigera on pigeon pea. Three concentrations of each cypermethrin and chlorpyrifos along with one untreated / control treatments were evaluated in replicated trials. In order to make comparison of effectiveness of pesticide treatment more valid, the Randomized block design can be effectively used.
\end{abstract}

Key words: RBD, field experiment, pesticidal effect.

\section{Introduction:}

Pigeon pea (Cajanus cajan 1.Millsp.) is an important pulse crop in Vidarbha. The crop yields are generally hampered by many pests, which are problematic over the years [1]. Major constraint in the production of pigeon pea is damage caused by insect pests with available losses extending up to 78percent in India [2]. Nearly 300 species of insects are known to infest pigeon peacrop at its various growth stages in India [3]. Pod borers caused 60 to 90 percent loss in the grain yield under favourable condition and damage of seed by pod fly ranged from 14.3 to 46.6 percent [4]. Gram pod borer (Helicoverpa armigera), tur plume moth (Exelastis atomosa) and tur pod fly (Melanogromyza obtusa) pests can be effectively managed by proper use of recommended pesticides [5].

Randomized block design has wider applicability and several treatments can be tried out together to evaluate the effectiveness of the selected pesticide concentration. Cypermethrin (25EC) and chlorpyrifos (20EC) are two pesticides which were selected for the treatments against pests on pigeon pea with different concentrations. The land on which trial to be carried out was divided into no. of blocks of same size and shape, as many treatments and concentrations were prepared. There were ' $T$ ' treatments and ' $R$ ' replications. Thus there are ' $R$ ' blocks and ' $R$ ' plots in each block, giving total 'TR' plots together. The treatments were allocated randomly to the ' $\mathrm{T}$ ' plots in block, randomization being carried out with the help of random numbers. The observations from the 'TR' plots furnish the data for comparison of treatments. The comparison were made using the analysis of variance technique. carried out.

To evaluate the effect of treatments against $\mathrm{H}$. armigera on pigeon pea a field trial with RBD was

\section{Material And Method:}

The experimental field was prepared by undertaking all necessary field operations. The field was prepared for sowing pigeon pea seeds and layout of field was done for the crop as per the statistical design (RBD) selected as follows. [6]

Plan of field Layout for trials: 


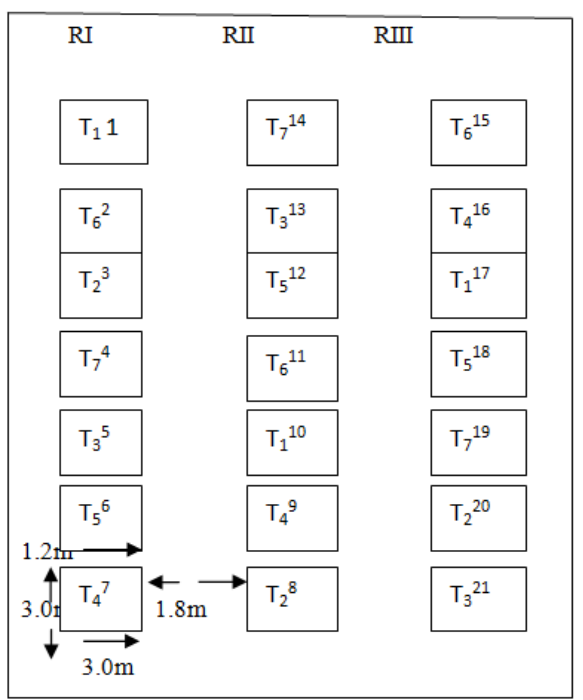

T1: Chlorpyrifos $(0.05 \%)$

T2: Chlorpyrifos $(0.07 \%)$

T3: Chlorpyrifos $(0.1 \%)$
Treatments:

T4: Cypermethrin $(0.0075 \%)$

T5: Cypermethrin $(0.0125 \%)$

T6: Cypermethrin $(0.0175 \%)$
T7: Water (untreated)

III. Details Of The Field Experiment:

\begin{tabular}{|c|c|c|c|c|c|}
\hline No. & Particulars & $\begin{array}{l}\text { Pigeon pea field } \\
\text { details }\end{array}$ & No. & Particulars & $\begin{array}{l}\text { Pigeon pea } \\
\text { field details }\end{array}$ \\
\hline 1 & Plan of layout & Refer fig 1 & 8 & Spacing & $60 \times 30 \mathrm{cms}$ \\
\hline 2 & Design & $\begin{array}{l}\text { R.B.D.(Randomized } \\
\text { Block Design) }\end{array}$ & 9 & Inter-replication spacing & $1.8 \mathrm{~m}$ \\
\hline 3. & No. Of treatments & 7 & 10 & Inter-plot spacing & $1.2 \mathrm{~m}$ \\
\hline 4 & No. of replications & 3 & 11 & Total no. of plants/plot & 50 \\
\hline 5 & Total no. of plots & 21 & 12 & Method of sowing & Dibbling \\
\hline 6 & Plot size & $3 m \times 3 m$ & 13 & $\begin{array}{l}\text { Cultural practices (fertilizers } \\
\text { etc.) }\end{array}$ & Recommended \\
\hline 7 & Crop variety & & 14 & No. of sprays & Two \\
\hline
\end{tabular}

Details of the insecticidal treatment against h. Armigera on pigeon pea:

\begin{tabular}{|c|c|c|c|c|}
\hline Sr.No. & Treatment No. & Insecticide & $\begin{array}{lr}\begin{array}{l}\text { Concentration } \\
\text { insecticide }\end{array} & \text { of } \\
\text { product) } & \text { (Trade }\end{array}$ & $\begin{array}{l}\text { Concentration } \\
\text { used in spray } \\
(\%)\end{array}$ \\
\hline 1 & T1 & Chlorpyrifos & $20 \mathrm{EC}$ & 0.05 \\
\hline 3 & T3 & Chlorpyrifos & $20 \mathrm{EC}$ & 0.1 \\
\hline 4 & T4 & Cypermethrin & $25 \mathrm{EC}$ & 0.0075 \\
\hline 5 & T5 & Cypermethrin & $25 \mathrm{EC}$ & 0.0125 \\
\hline 7 & T7 & Untreated(Control) & $\begin{array}{l}---- \\
\end{array}$ & ----- \\
\hline
\end{tabular}

Using the plan of layout as shown in fig. 1 spraying was done on pigeon pea crop. The first spraying was done at the $50 \%$ flowering seen on pigeon pea and the second spraying was followed after 15 days of interval as per the treatment details.

The method used for noting down the observations included selection of five plants from each plot randomly and tagged as observational plants. At the time of harvesting of pigeon pea 20 pods were randomly collected from each observational plant. Thus total 100 pods were collected from each block. From these collected pods no. of infested/ damaged pods were counted due to Helicoverpa armigera pests.

For the purpose of calculation of percentage pod infestation due to Helicoverpa armigera, single observation recorded was used at the time of harvesting. Thus percentage pod damage in case of each treatment was worked out. The large holes seen in the pods were considered as damaged due to Helicoverpa armigera and no. noted accordingly. 


\section{Statistical Analysis:}

From observations taken from three replicated plots one from each row, percentage pod damage and percentage reduction over control were calculated using following formula,

Pod Damage $\%=\frac{\text { No.of damaged pods }}{\text { Total No.of pods examined }} \times 100$

$\%$ Reduction over control $=\frac{100 \times(\text { Difference between control \& reading })}{\text { Reading of control }}$

The data generated of percentage pod damage due to pod borer in pigeon pea was first transformed to arcsin values as per method suggested by Gomez and Gomez [7] and then these values were subjected to statistical analysis of the data for the test of significance (CD at 5.0 percent level) as per statistical method suggested by Panse and Sukhatme [8].

\section{Result And Discussion:}

Based on percentage infestation of Helicoverpa armigera on pigeonpea all insecticidal treatments were significant and superior over untreated control against the pest. The results obtained were supported by previously done work by following researchers.

Ram Ujagir [9] reported lowest pod damage with treatment with cypermethrin and gave an effective level of control of Helicoverpa armigera and a higher grain yield compared to untreated plots. Kumar and Nath [10] evaluated the efficacy of some synthetic insecticides i. e. cypermethrin, fenvalerate and deltamethrin against pests infesting pigeon pea and found among these insecticides cypermethrin showed better results even as compared to control/ unreated plot.[Pinki Bhandari and Ram Ujagir [11] determined that chlorpyrifos when sprayed against the pod borer complex of early maturing pigeon pea was effective. Kripal Singh Sharma [12] investigated that both chlorpyrifos and cypermethrin showed low pod damage when sprayed on pigeonpea.

Table 1: Percentage pod damage in pigeonpea by pod borer, $\mathrm{H}$. Armigera with respect to insecticidal schedules before harvesting

\begin{tabular}{|l|l|l|l|l|l|l|}
\hline Plot & Row 1 & Row 2 & Row 3 & Mean & Pod damage \% \\
& & & & & & \\
\hline T1 (0.05) Chlorpyrifos20EC & 13 & 14 & 13 & 13.33 & 13.33 & 24.52 \\
\hline T2 $(0.07)$ Chlorpyrifos20EC & 8 & 8 & 9 & 8.33 & 8.33 & 52.83 \\
\hline T3 $(0.1)$ Chlorpyrifos20EC & 6 & 7 & 7 & 6.65 & 6.65 & \\
\hline T4(0.0075)Cypermethrin25EC & 16 & 15 & 15 & 15.33 & 15.33 & 62.34 \\
\hline T5(0.0125)Cypermethrin25EC & 12 & 13 & 10 & 11.66 & 11.66 & 13.19 \\
\hline T6(0.0175)Cypermethrin25EC & 7 & 5 & 8 & 6.66 & 6.66 & 33.98 \\
\hline T7 Control & 18 & 19 & 16 & 17.66 & 17.66 \\
\hline
\end{tabular}

Graph 1: Showing comparative percentage pod damage in pigeonpea by pod borer, H. Armigera with respect to insecticidal schedules before harvesting

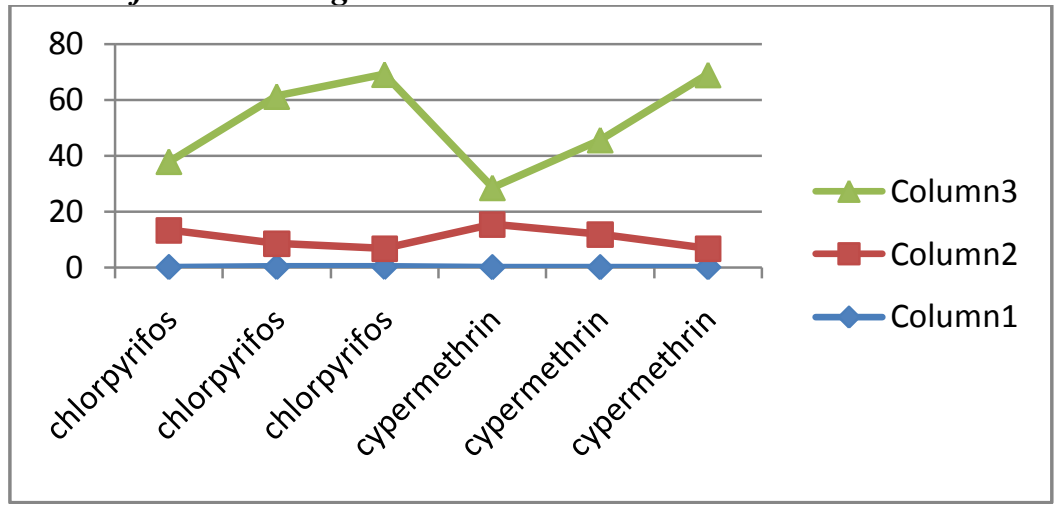

Table 2: Percentage pod damage in pigeonpea by pod borer, $\mathrm{H}$. Armigera with respect to insecticidal schedules after harvesting

\begin{tabular}{|c|c|c|c|c|c|c|}
\hline Plot & Row 1 & Row 2 & Row 3 & Mean & Pod damage $\%$ & $\begin{array}{l}\text { \%Reduction } \\
\text { over control }\end{array}$ \\
\hline T1 (0.05) Chlorpyrifos20EC & 16 & 17 & 17 & 16.33 & 16.33 & 15.52 \\
\hline T2 (0.07) Chlorpyrifos20EC & 13 & 11 & 8 & 10.66 & 10.66 & 44.85 \\
\hline T4(0.0075)Cypermethrin25EC & 18 & 17 & 18 & 17.66 & 17.66 & 8.64 \\
\hline T5(0.0125)Cypermethrin25EC & 14 & 13 & 14 & 13.66 & 13.66 & 29.33 \\
\hline T6(0.0175)Cypermethrin25EC & 11 & 9 & 9 & 9.33 & 9.33 & 51.73 \\
\hline
\end{tabular}


Graph2: Showing percentage pod damage in pigeonpea by pod borer, H. Armigera with respect to insecticidal schedules after harvesting

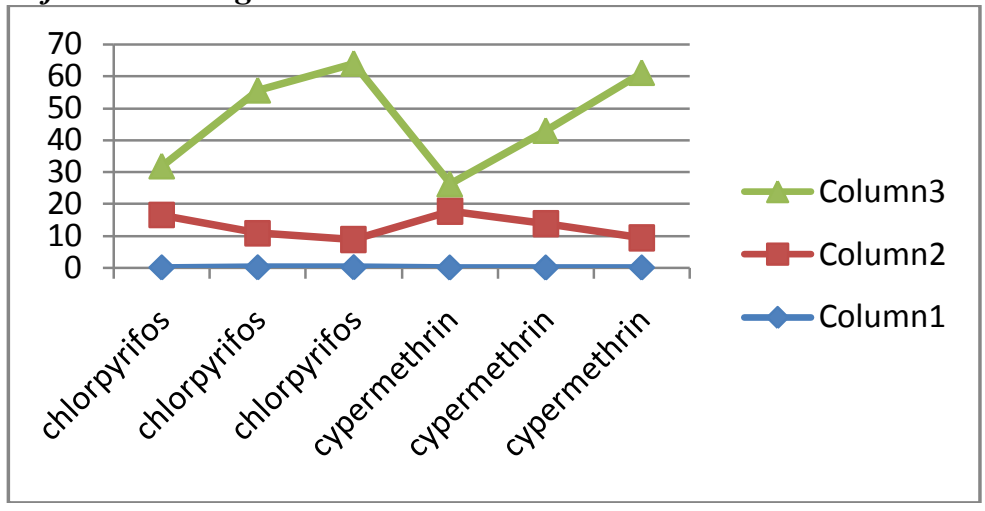

VI. Conclusion

In present study RBD was used in field experiment for evaluation of effectiveness of pesticidal treatments with different concentrations against pod borer (H.armigera).

The results obtained in the pigeonpea findings showed that chloropyrifos was more effective even with low concentration than cypermethrin to control infestation on pigeon pea pods by H. armigera. .

Thus, to evaluate the effect of selected pesticide with different concentrations in the field experiment, plan of layout as randomized block design (RBD) could be effectively used.

\section{Reference:}

[1]. Kumar and Nath, 2002): Kumar A. and Nath P.(2002). Effect of insecticides on loss in seed mass and yield of pigeonpea by pod borer. International chickpea and pigeonpea Newsletter. 10:50-51.

[2]. Lateef and Reed, 1983).: Lateef S.S. and Reed W. 1990. Insect pests of pigeonpea. In Insect pests of Tropical Food Legumes, ed.S.R.Singh,pp193-242. Chichester,UK:Wiley.pp451.

[3]. Lal and Singh, 1998).:Lal S.S.and Singh N.B.(1998). In Proceedings of National Symposium on Management of Biotic and Abiotic Stressesin Pulse Crops. Indian institute of Pulse Research, Kanpur, India, pp65-80.

[4]. Lal et. al., 1992).: Lal C., Sharma S.K.and Chahota R.K. (1992). Oviposition responseof pod fly (Melanagromyza obtusa) on resistant pigeonpea (Cajanus cajan)selections.Indian Journal of Agricultural science. 64:658-660.

[5]. Anonymous, 1998 Plant Protection Recommendations. Commisionarate of Agriculture, Maharashtra State, Pune (Information Bulletion No.1483)

[6]. Vaidya et. al., 1993): Vaidya V.G, Sahastrabudhe K.R. and Khupse V.S.1993,Crop production and field experimentation,book published by continental Prakashan, PP.492-496.

[7]. Gomez and Gomez(1984): Gomez K.A.and Gomez A.A. 1984. Statistical procedures for agricultural research. John Wiley and sons, New York, 207-215pp.

[8]. Panse and Sukhatme (1967): Panse V.G. and Sukhatme p.V.1967 Statistical method for agricultural workers. ICAR, New delhi second edition 1967.

[9]. Ram Ujagir (1999). Field efficacy of insecticides against pod borer complex in early pigeonpea,Cajanus cajan (L.) Millsp.at Pantnagar, Northen India. Annals of Plant Protection Sciences. 7 (1): 19-25.

[10]. Kumar and Nath (2003): Kumar A. and Nath P.(2003). Effect of insecticides on extent of pod damage and seed damage by pod fly, Melanagromyza obtusa (Malloch) and pod borer. Helicoverpa armigera (Hubner) in bahar cultivar of pigeonpea. Annals of Agricultural Research. 24(4):934-942.

[11]. Pinki Bhandari and Ram Ujagir (2002). Bioefficacy of certain insecticides against pod borer complex of early pigeon pea, Cajanus cajan (L.) Millsp. Annals of Plant Protection Sciences. 10 (2): 225-229.

[12]. Kripal Singh Sharma, J.P. (2003). Efficacy and economics of certain insecticides in the management of pod borer in chickpea. Indian Journal of Pulses Research 16 (2):167-168. 